Article

\title{
Impacts of Relative Elevation on Soil Nutrients and Apple Quality in the Hilly-Gully Region of the Loess Plateau, China
}

\author{
Lei Hua ${ }^{1,2,3,4,5}$, Jianen Gao ${ }^{1,3,4,5, *}$, Meifang Zhou ${ }^{3,4}$ and Shilun Bai ${ }^{6}$ \\ 1 Institute of Soil and Water Conservation, Chinese Academy of Sciences and Ministry of Water Resources, \\ Yangling 712100, China; hualei2020@126.com \\ 2 Department of Computer Science and Technology, Xi' an University of Science and Technology, \\ Xi'an 710054, China \\ 3 Institute of Soil and Water Conservation, Northwest Agriculture \& Forestry University, \\ Yangling 712100, China; zmeifang2021@163.com \\ 4 Research Center on Soil \& Water Conservation, Ministry of Water Resources, Yangling 712100, China \\ 5 College of Resources and Environment, University of Chinese Academy of Sciences, Beijing 100049, China \\ 6 Ansai District Bureau of Meteorology, Ansai 717400, China; bs15452@163.com \\ * Correspondence: gaojianen@126.com
}

Citation: Hua, L.; Gao, J.; Zhou, M.; Bai, S. Impacts of Relative Elevation on Soil Nutrients and Apple Quality in the Hilly-Gully Region of the Loess Plateau, China. Sustainability 2021, 13, 1293. https://doi.org/10.3390/ su13031293

Academic Editor: Xining Zhao

Received: 2 December 2020

Accepted: 21 January 2021

Published: 26 January 2021

Publisher's Note: MDPI stays neutral with regard to jurisdictional claims in published maps and institutional affiliations.

Copyright: (c) 2021 by the authors. Licensee MDPI, Basel, Switzerland. This article is an open access article distributed under the terms and conditions of the Creative Commons Attribution (CC BY) license (https:// creativecommons.org/licenses/by/ $4.0 /)$.

\begin{abstract}
Relative elevation, as one of the decisive factors to the redistribution of soil water, nutrients, sunshine, and temperature in a region influences apple yield and quality by adjusting soil water and nutrients. To explore the impact of relative elevation on apple quality, this research investigated the conditions of soil moisture and nutrients at different elevations of terrace apple orchards in the hilly-gully region of the Loess Plateau. The results showed that soil water content decreases when the elevation increased, whereas soil nutrients fluctuated significantly at different elevations of terrace orchards and the contents were lower than the standard level of the Loess Plateau, especially soil organic matter, but total potassium was higher. The apple firmness increased when the elevation increased and had a good linear relationship with elevation. Apple vitamin C content in weedcovered orchards was higher than in the ploughing and weeding management orchards. The impact of soil nutrients, including soil water, nitrogen, phosphorus, and potassium on apple quality were concentrated in soluble solid and total acid. Irrational irrigation or partial use of nutrients, such as more use of nitrogen and less use of phosphorus and potassium, may deteriorate the apple quality. Therefore, we suggested that the amount of irrigation be increased appropriately with the raising of elevation. Moreover, part of the weed should be kept to cover the orchard, as well as mowing regularly and covering the surface. This would not only improve water use efficiency and increase soil organic matter content, it would also maintain apple quality and ensure sustainable development of the apple orchards.
\end{abstract}

Keywords: apple orchard; soil water and nutrients; fruit quality; arid and semi-arid area

\section{Introduction}

The Loess Plateau, an arid and semi-arid region in China, is one of the most serious areas of soil erosion in the world [1-4]. Severe soil erosion resulted in fragmented landscapes in the Loess Plateau [5,6], where a slope of less than $5^{\circ}$ accounts for $43 \%, 5^{\circ}-15^{\circ}$ accounts for $35 \%, 15^{\circ}-25^{\circ}$ accounts for $17 \%$, and more than $25^{\circ}$ accounts for $5 \%$ of the total area $\left(640,000 \mathrm{~km}^{2}\right)$. Slope steepness of more than $15^{\circ}$ is concentrated in the hilly-gully region of the Loess Plateau. To control soil erosion and develop the regional economy, the Chinese government built terraces along contour lines on the slope, above $5^{\circ}$ on the Loess Plateau, and combined with the "Grain for Green" project [7-10], formed the terrace apple orchards that integrated soil water conservation projects with economic development on the Loess Plateau (especially in the northern region). In recent years, the apple industry on the Loess Plateau has expended rapidly, accounting for a quarter of China's apple yield and one-seventh of the world's apple yield [11,12]. 
The northern part of the Loess Plateau is a high-quality apple-producing area due to its special geographic location and natural conditions, including high elevation, soil texture, abundant sunshine, and large temperature difference between day and night [13]. As of 2018, the area of apples in the north of the Loess Plateau reached $2310 \mathrm{~km}^{2}$. It is expanding rapidly, at a rate of $130 \mathrm{~km}^{2}$ per year [14]. Soil moisture and nutrients are the dominant factors that influence the apple yield and quality. Reasonable regulation of soil water and nutrients will increase apple yield, improve apple quality, and obtain maximum benefits for a limited amount of water and fertilizer input. Water shortage is a disadvantage in the Loess Plateau when it comes to developing the apple industry; thus, scholars have proposed water collection and irrigation techniques, such as sprinkler irrigation, drip irrigation, and root irrigation to replenish the lack of water in the main stages of apple growth (bud burst to leafing, flowering to fruit set, and fruit growth) $[12,15,16]$. However, most of the research overlooks the impact of relative elevation on apples.

As the spatial variable, relative elevation directly affects soil water movement and redistribution. Soil water is the driving force for nutrient transport, the transmission and absorption of water by plant roots will change the distribution and utilization efficiency of nutrients. Soil water content is heterogeneous in different elevation positions, which has great influence on apple yield and quality. To explore the impact of relative elevation on apple quality, this research investigated the conditions of soil moisture and nutrients at different elevations of terrace apple orchards in Ansai County, Yan'an City. Then, we analyzed the relationship among soil moisture, nutrients, and apple quality with relative elevation, and proposed improved orchard management measures to maintain apple yield and quality at different elevations of apple orchards. This research can lead to improved orchard management, by keeping a stable and high-quality apple industry development in the mountain orchards.

\section{Materials and Methods}

\subsection{Study Area}

Terrace apple orchards in Ansai District, Yan'an City, are located in the central part of the Loess Plateau (Figure 1a). The research area is in a mid-temperate continental semi-arid monsoon climate, with an average annual temperature of $9.1^{\circ} \mathrm{C}$, and has a large temperature difference between day and night. The area has 2396 annual sunshine hours. The maximum monthly sunshine hours, which occur in June, are up to $262 \mathrm{~h}$. The average precipitation is $506 \mathrm{~mm}$, in which $60 \%$ of rainfall is concentrated from July to September. The total area of the Ansai District is $2950 \mathrm{~km}^{2}$, in which the farmland accounts for $709.33 \mathrm{~km}^{2}$ and $95 \%$ of it is on the slope (slope gradient $>5^{\circ}$ ). The main soil type in this region is the loess soil, and it has a deep soil layer. The primary apple cultivar in this region is the Red Fuji apple, and the fruit trees are generally pruned into spindle-shape structures.

The field experiments were conducted at different elevations of terrace apple orchards. The apple cultivar in the study area is the Red Fuji apple. On a north slope, from April to November 2016, the field elevation ranged from 1180-1240 m. We selected six terrace apple orchards, which were defined as terrace 1 (T1), terrace 2 (T2), terrace 3 (T3), terrace 4 (T4), terrace 5 (T5) and terrace 6 (T6) from bottom to top (Figure 1b). The T3 orchard had natural growth; however, the orchard was abandoned and there was no orchard management. Others had normal management, namely fertilization (mainly chemical fertilizer) in different stages of apple growth (bud burst to leafing, flowering to fruitlets set, and fruit growth); thinning flowers and fruits during the flowering and fruitlet-set periods; ploughing and weeding during the weed flourishing stages; and pruning in the summer and winter (Table 1). Soil properties, including soil bulk density, porosity, and $\mathrm{pH}$ were $1.21-1.66 \mathrm{~g} / \mathrm{cm}^{3}, 0.39-0.64 \%$, and $6.02-7.36$ in $0-40 \mathrm{~cm}$ soil layer, respectively. To keep the apple yield and quality, the farmers replaced the old and sick trees. Therefore, the apple trees were between 8 and 20 years old. The row spacing and column spacing between apple trees were $4 \mathrm{~m}$ and $5 \mathrm{~m}$, respectively. 


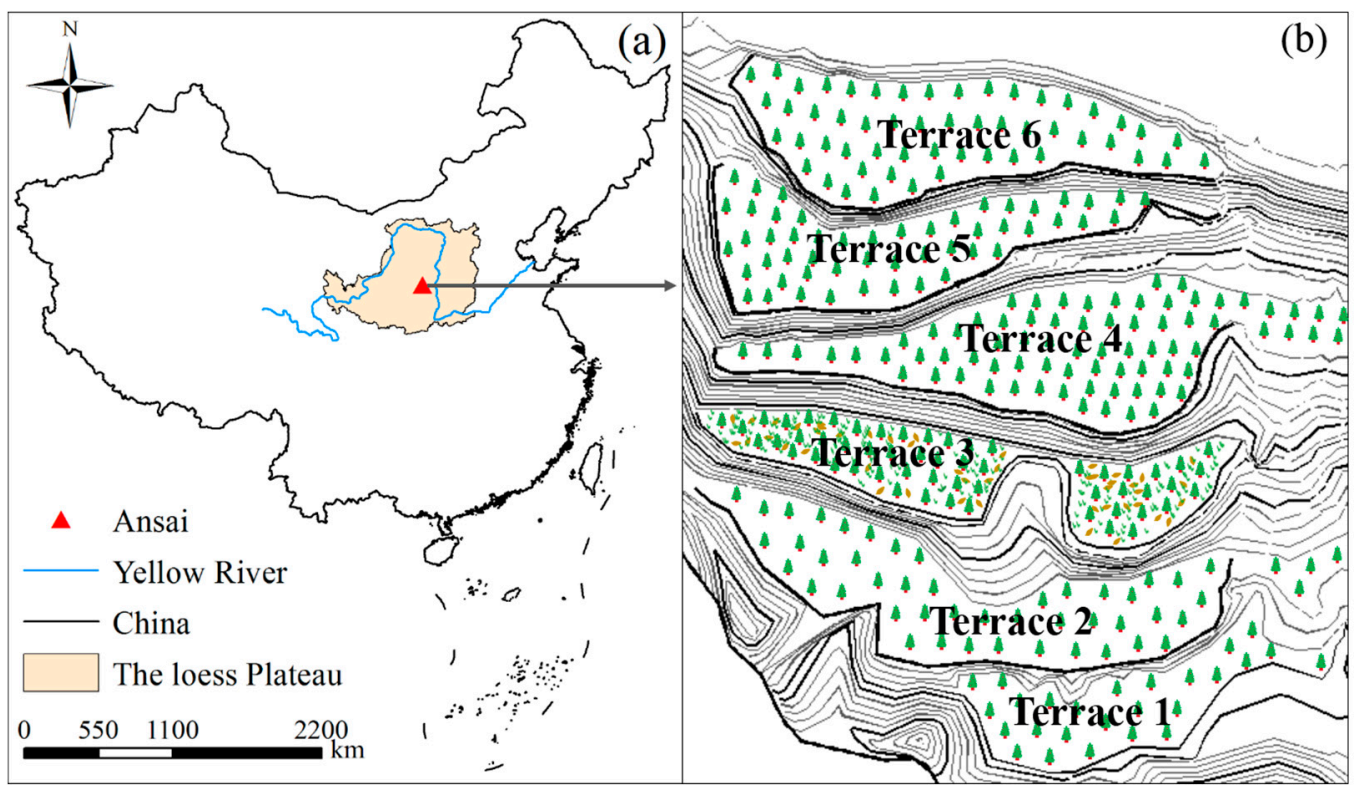

Figure 1. Geographic location of the study area. (a) The location of Aansai Distinct; (b) terrace apple orchards at different elevation in Ansai Distinct.

Table 1. The specific situations of sampling sites at different elevations of terrace apple orchards.

\begin{tabular}{cccc}
\hline Orchards & Elevation $(\mathbf{m})$ & Tree Age (Year) & Management \\
\hline Terrace 1 & 1182 & $12-20$ & Normal \\
Terrace 2 & 1191 & $15-20$ & Normal \\
Terrace 3 & 1196 & $16-20$ & Abandoned \\
Terrace 4 & 1203 & $8-20$ & Normal \\
Terrace 5 & 1215 & $13-20$ & Normal \\
Terrace 6 & 1236 & $15-20$ & Normal \\
\hline
\end{tabular}

\subsection{Samples Collection and Processing}

According to the " $Z$ " shape or five point sampling method, we chose five apple trees in each terrace orchard, which had similar age and status and a distance (with field ridge and slope foot). Affected by the terrain, all of the sampling sites on the orchards were placed on the southwest slope, except for the T4 orchard, where sampling sites were collected on the south slope. Twenty apples on each of the selected trees were picked from different directions and positions in the middle canopy layers. Then, the content of soluble solids, total sugar, firmness, vitamin C, and total acid in fresh apples were detected. Soil samples were collected under each selected apple tree at the position where there was no local fertilization, and was $1.5-2.0 \mathrm{~m}$ from the trunk. To avoid the direct impact of fertilization on soil nutrient evaluation in the physiological periods, the soil sampling time happened at the end of October 2015. Total sampling depth was $2.0 \mathrm{~m}$, which was divided into seven layers; the top layer was $0-1.0 \mathrm{~m}$ and was evenly divided into five layers (the step was $0.20 \mathrm{~m}$ ); the middle layer was $1.0-1.5 \mathrm{~m}$, and only one layer; the bottom layer was $1.5-2.0 \mathrm{~m}$ and only one layer as well. We used soil auger to take soil mass in each layer and took out $50 \mathrm{~g}$ of well-mixed soil samples to measure soil water content and nutrients.

\subsection{Measurement Items and Methods}

Soil water content was determined by the oven drying method. The maximum/minimum soil water content was decided by comparing the content in different sampled soil layers, from 0 to $200 \mathrm{~cm}$. Soil organic matter (OM) content, total potassium (TK), total nitrogen (TN), and total phosphorus (TP) were measured according to Shidan Bao (2000) [17] (Table 2). 
Table 2. Testing items and methods for soil nutrients.

\begin{tabular}{ccc}
\hline Items & Methods & Instruments \\
\hline Organic matter & Potassium dichromate outside heating & Semi-micro titrator \\
Total potassium & NaOH liquation & Flame photometer \\
Total nitrogen & NaOH alkaline hydrolysis with & Automatic Kjeldahl nitrogen \\
Total phosphorus & reducing agent-diffusion process & determination apparatus \\
\hline
\end{tabular}

The apple soluble solids, total sugar, firmness, vitamin C, and total acid were used to characterize the comprehensive apple quality in this research. The methods/instruments for determination of the content of these items referred to the national or international standards for fruits and vegetables, as seen in Table 3.

Table 3. Testing items and methods/instruments for soil nutrients.

\begin{tabular}{ccl}
\hline Item & \multicolumn{1}{c}{ Methods/Instrument } & \multicolumn{1}{c}{ Note } \\
\hline Total sugar & Fehling's solution titration [18] & The index of apple quality was \\
Total acid & Potentiometric titration [18] & $\begin{array}{l}\text { measured by the Food Detection } \\
\text { and Identification Center of }\end{array}$ \\
Vitamin C & 2-6-diohloroindophenol titration [19] & Northwest Agriculture \& Forestry \\
Soluble solids & Refractometer [20] & University \\
Firmness & Fruit firmness meter [21] & \\
\hline
\end{tabular}

\section{Results and Discussion}

\subsection{Distribution Characteristics of Soil Moisture in Orchards at Different Elevations}

Figure 2 shows the variation of soil water content within $0-80 \mathrm{~cm}$ (root layer) and 0-200 cm (measured layer) at different elevations of terrace apple orchards. Apple trees are in a relatively dense layer of roots at $0-80 \mathrm{~cm}$, in which the root systems need to uptake a great amount of water to supply apple tree growth and production [22]. Therefore, this section compares the change of soil moisture in the root layer and the measurement layer. The results indicate that the soil water content in the root layer is higher than the measured layer; the trends of soil water content with elevation in both the root layer and the measured layer are the same, which has a downward trend when the elevation increases. The soil water content in the root layer is $11-17 \%$, and $9-15 \%$ in the layer of $0-200 \mathrm{~cm}$. The highest soil moisture content appears in orchard T3, which is an abandoned and uncultivated orchard; the soil is compact, the surface is covered by weeds and litter, and the apple trees are not pruned. Therefore, the surface evapotranspiration is low and the soil moisture is better than the orchards that were ploughed and with bare surface. Soil water content in orchard $\mathrm{T} 5$ is higher than in orchard T4, which is more likely influenced by the slope aspect. The lowest soil moisture appears in orchard T6, which is located at the highest elevation, because of abundant sunshine and high evapotranspiration. This suggests that elevation and orchard management have important effects on soil moisture.

Figure 3 denotes that soil water content in the T3 apple orchard has the smallest difference between the maximum and minimum soil water content, while the greatest difference between the maximum and minimum soil water content appears in the T6 apple orchard, which is located at the highest elevation. Moreover, the maximum soil water content in 0-200 cm is consistent with the surface layer $(0-20 \mathrm{~cm})$. Compared with other terrace apple orchards, the maximum soil water content occurs in the T3 apple orchard. However, the minimum soil water content appears below the root layer $(0-80 \mathrm{~cm})$ at different elevations of terrace apple orchards. Therefore, the terrace apple orchards should be irrigated opportunely, according to the situation of soil water content in the root zone, especially at higher elevations of terrace apple orchards. 


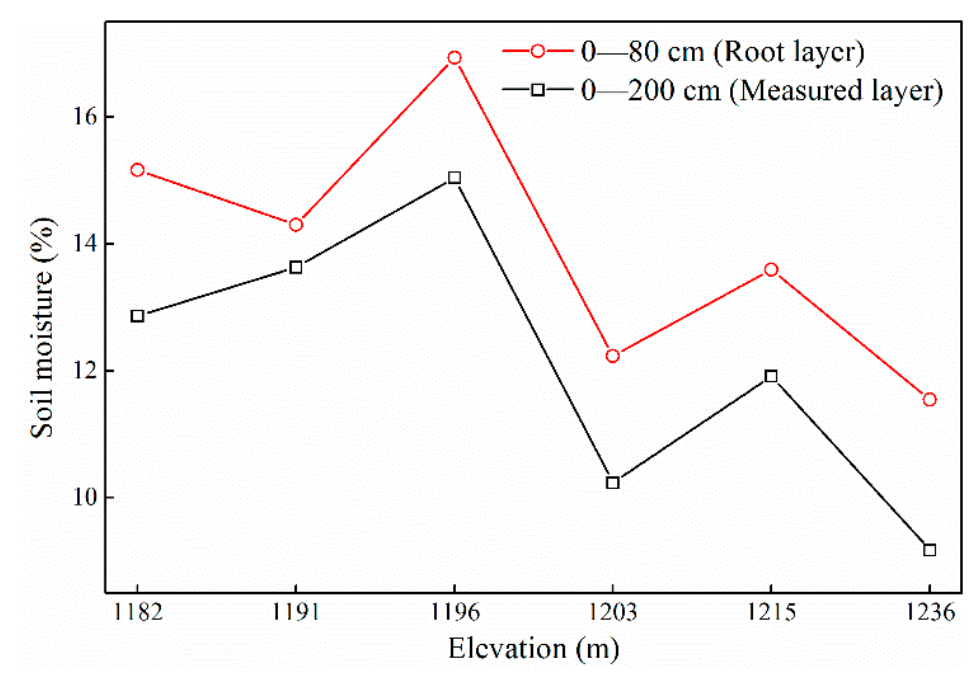

Figure 2. Soil moisture in root layer $(0-80 \mathrm{~cm})$ and measured layer $(0-200 \mathrm{~cm})$ at different elevation of terrace apple orchards.

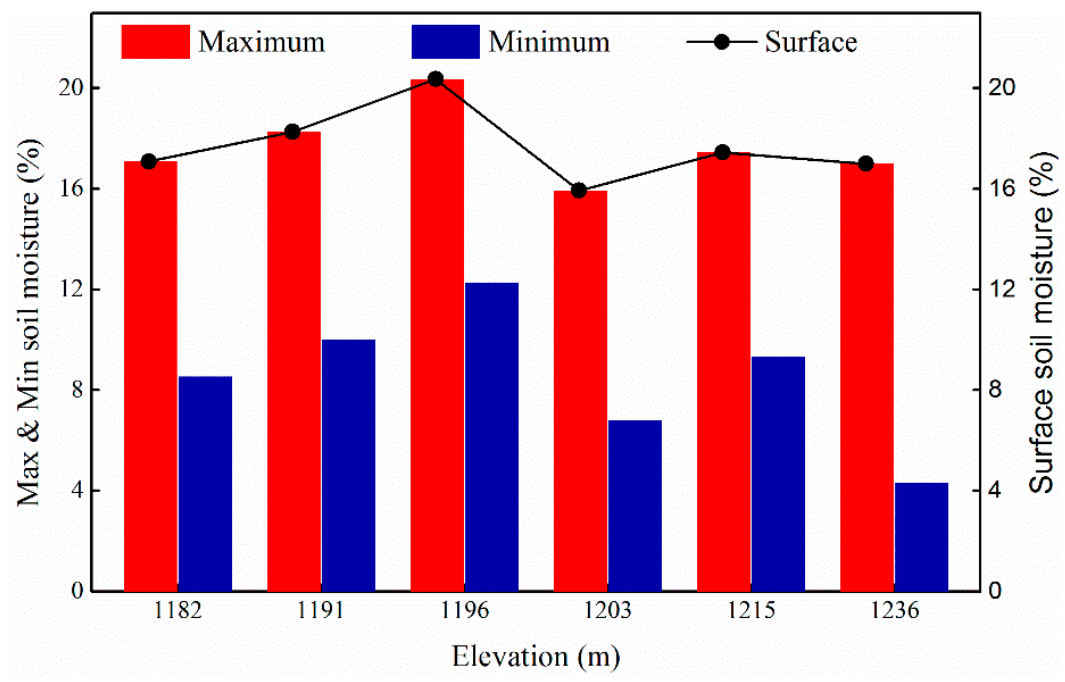

Figure 3. Maximum, minimum, and surface soil moisture at different elevations of terrace apple orchards.

\subsection{Status of Soil Nutrients in Orchards at Different Elevations}

Figure 4 shows the variation of soil nutrients in root layers at different elevations of terrace apple orchards; the variations of soil nutrients in apple orchards are mainly concentrated in the root layers $(0-80 \mathrm{~cm})[23,24]$. The differences in content of soil nutrients among the terrace apple orchards (mean \pm standard deviation, $n=3$ ) were compared by the analysis of variance (ANOVA) and a Duncan test at a probability of $5 \%(p=0.05)$ significant level. Figure 4a indicates the contents of soil OM on the orchards of T1, T3, T4, and $\mathrm{T} 5$ have significant difference with T2 and T6, while the contents of TK among the T1, $\mathrm{T} 3$, and $\mathrm{T} 4$ are almost the same, but those have a significant difference with $\mathrm{T} 2$, $\mathrm{T} 5$, and $\mathrm{T} 6(p<0.05)$. Figure $4 \mathrm{~b}$ demonstrates that TN content on the orchards of T1 and T4 are obviously different from $\mathrm{T} 6, \mathrm{TN}$ content on $\mathrm{T} 2, \mathrm{~T} 3$, and $\mathrm{T} 5$ are significantly higher than $\mathrm{T} 4$. TP content at the different elevations of apple orchards have significant differences. Soil nutrients fluctuate when the elevation increases, the content of soil OM, TK, TN, and TP are in the ranges of $4.82-7.54 \mathrm{~g} / \mathrm{kg}, 17.19-19.58 \mathrm{~g} / \mathrm{kg}, 0.28-0.68 \mathrm{~g} / \mathrm{kg}$, and $0.59-0.99 \mathrm{~g} / \mathrm{kg}$, respectively. According to the standard ranges of soil nutrient content in the apple orchards of the Loess Plateau [25], the content of OM, TK, TN, and TP are in the ranges of $12-18 \mathrm{~g} / \mathrm{kg}$, $13-15 \mathrm{~g} / \mathrm{kg}, 0.6-1.0 \mathrm{~g} / \mathrm{kg}$, and $0.9-1.4 \mathrm{~g} / \mathrm{kg}$, respectively. The general status of soil nutrient 
content, including OM, TK, TN, and TP are low, especially OM, but TK content is higher than the standard level in the study area.
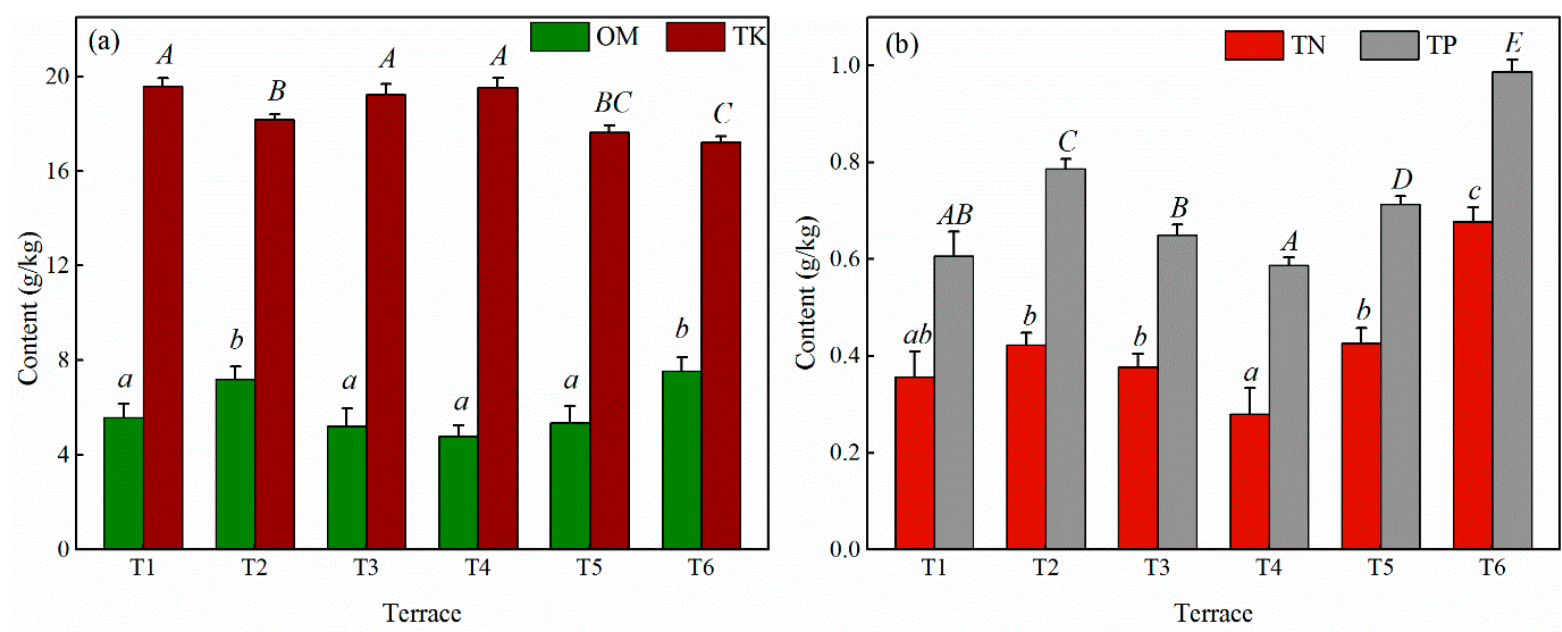

Figure 4. Variation of soil nutrients in root layers $(0-80 \mathrm{~cm})$ at different elevations of terrace apple orchards. (a) The content of soil organic matter and total potassium; (b) the content of total nitrogen and phosphorus. The capital and lowercase letters represent the significant differences in soil nutrients between different terraces.

Organic litter, such as leaves and branches, is the main source of soil OM [26-28]. In the hilly and gully region of the Loess Plateau, surface runoff is the driving force for litter transportation. Terraces part slopes and form continuous stages; the surface runoff is restricted and promoted to infiltration in situ. Therefore, the organic litter collects and decomposes onsite and there is little change in soil OM from the foot to the top orchards. Moreover, the organic fertilizer is seldom supplied to the orchards because of inconvenient transportation; therefore, soil OM content is low in this area. The impact of soil parent materials and orchard maintenance, mainly fertilizing, leads to the spatial heterogeneity of TK, TN, and TP. For the sake of sustainable development of the apple industry in this region, soil organic matter, $\mathrm{TN}$, and $\mathrm{TP}$ should be appropriately added to maintain soil productivity and apple quality.

\subsection{Variation of Apple Quality at Different Elevations}

Figure 5 shows that soluble solids content in apples has little fluctuation at different elevations of terrace orchards, in the range of $14.5-17.1 \%$. According to the requirements of soluble solids for premium red Fuji apples in China (soluble solids content is no less than 13\%) [29], the soluble solids content of apples in this area is up to the level. The total sugar content in apple waves is in the range of $12.2-13.6 \%$, and the maximum appears in the highest terrace orchard. The soluble solids and total sugar content in orchard T4 distinguished slope aspect with other orchards, are lowest, and have little obvious variations at different elevations of terraces. Therefore, the impact of slope aspect, which directly influences the orchard sunshine, soil moisture, and temperature on soluble solids and total sugar content in apples, may be greater than the relative elevation. 


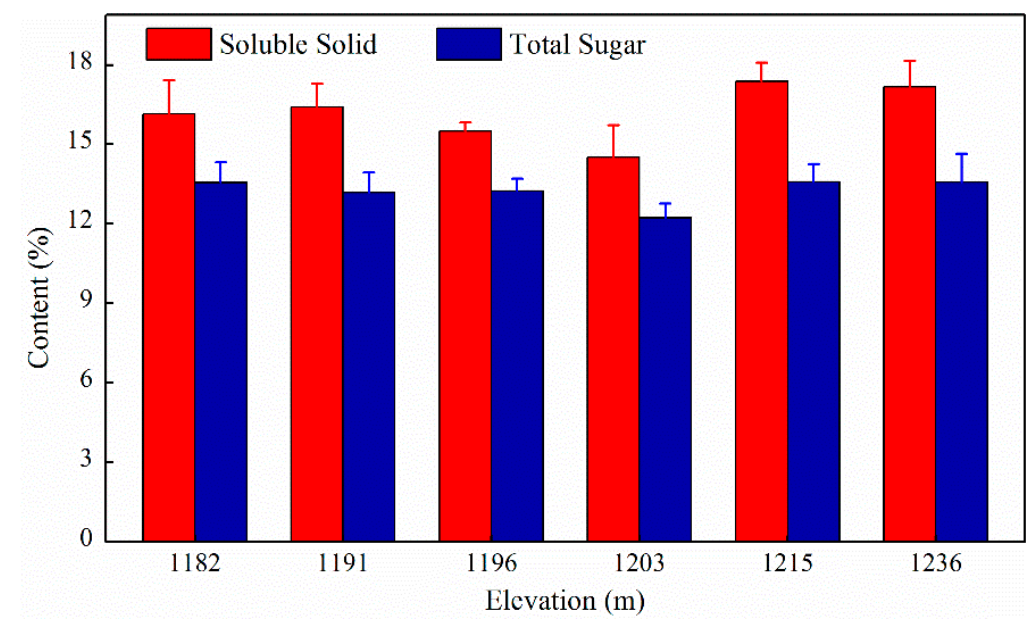

Figure 5. The soluble solids content and total sugar in apples at different elevations of terrace orchards.

Figure 6 illustrates that relative elevation has a significant effect on apple firmness $(p<0.05)$. Apple firmness increases when the elevation raises on the same orchard maintenance (orchard T1, T2, T4, T5, and T6), and there is a good linear relationship between apple firmness and relative elevation. As an important factor affecting apple storage time, the higher content of apple firmness is good for storage, but bad for apple taste. According to the requirements of firmness for premium red Fuji apples in China (the apple firmness is in a range of $\left.6.5-10 \mathrm{kgf} / \mathrm{cm}^{2}\right)[29,30]$, the apple firmness in the study area ranges from $6.7 \mathrm{kgf} / \mathrm{cm}^{2}$ to $9.9 \mathrm{kgf} / \mathrm{cm}^{2}$, and it satisfies the criteria. The apple firmness in orchard T3 sharply decreased and was less than the average apple firmness $8.05 \mathrm{kgf} / \mathrm{cm}^{2}$ of orchards $\mathrm{T} 2$ and T4, this difference was caused by the orchard management. According to the research by Li et al. [31] and Gao [32], apple firmness has a positive relationship with $\mathrm{Ca} /(\mathrm{K}+\mathrm{Mg})(\mathrm{Ca}, \mathrm{K}$, and $\mathrm{Mg}$ are the elements of calcium, potassium, and magnesium, respectively), and the $\mathrm{Ca} /(\mathrm{K}+\mathrm{Mg})$ would decrease when soil water increased. Orchard T3 was an abandoned orchard and soil water content was higher than the others. Therefore, the apple firmness declined abruptly at the same elevation, which implies that orchard maintenance has a great impact on apple firmness.

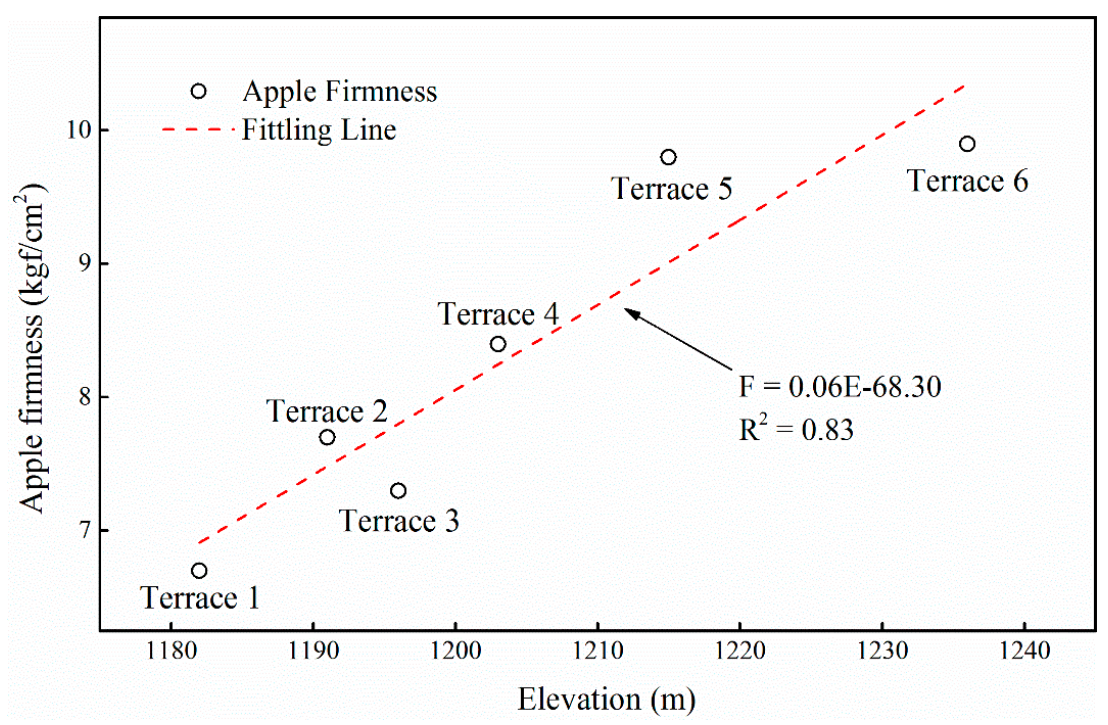

Figure 6. Apple firmness in different elevations of terrace apple orchards. In the equation, $\mathrm{F}$ represents the apple firmness, and E the elevation. Terrace 1-Terrace 6 refer to the terrace orchards at different elevations. 
Figure 7 indicates that the maximum content of apple vitamin $C$ is discovered in the T3 apple orchard, while the minimum is detected in the T2 apple orchard. Apple vitamin C content has the same trends with soil water content in the root zone as elevation increases, except for orchard T4, where slope aspect is different from the others. According to the study by $\mathrm{Li}$ et al. [33], apple vitamin C content in weed-covered orchards was significantly higher than the ploughing and weeding management orchards in an arid and semi-arid region. Therefore, apple vitamin $\mathrm{C}$ content has a close relationship with orchard management.

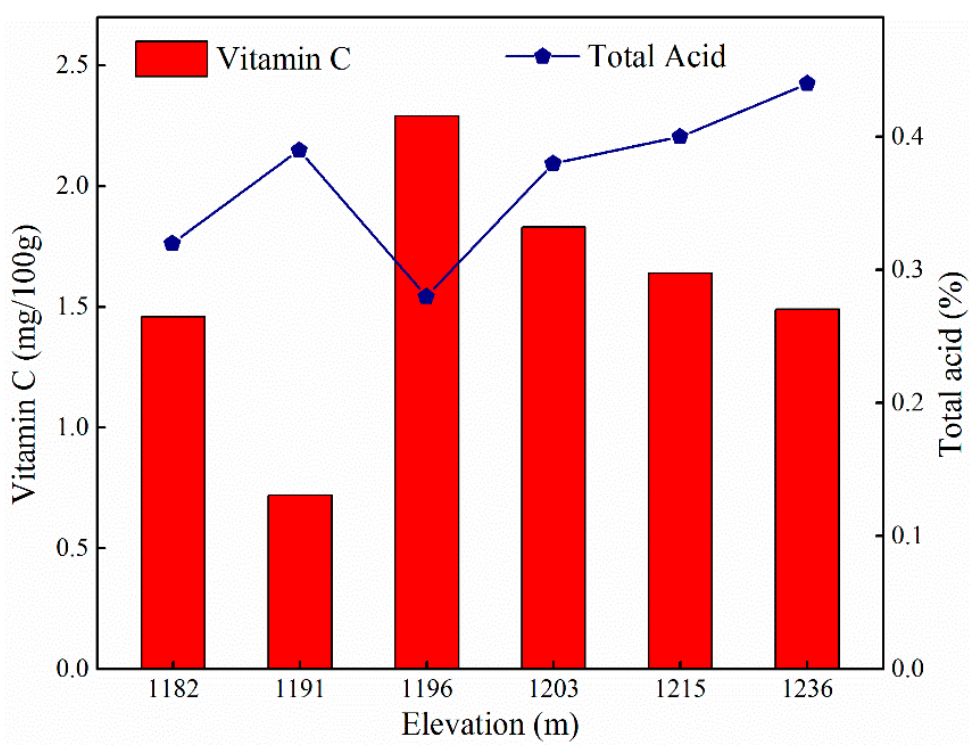

Figure 7. Variations of vitamin $\mathrm{C}$ and total acid content at different elevations of terrace apple orchards.

Apple total acid content fluctuates around $0.28-0.44 \%$ in this area, while the maximum apple total acid content is in the highest elevation of the terrace orchard (T6) and the minimum is in the T3 orchard. Soil water in the root zone is the primary factor to affect the total acid content in apples at the lower elevation of apple orchards (T1-T3), but the relative elevation is the dominating factor to influence the total acid content at the higher elevation of apple orchards (T4-T6). Soil water content in the root zone is lowest in the T2 apple orchard, but the total acid content of apples is highest at the lower elevation of terrace orchards. The total acid content in apples at the lower elevation has a negative relationship with soil water content in the root zone, while the total acid at the higher elevation has a positive relationship with relative elevation. According to the requirements of the total acid content for premium red Fuji apples in China (the total acid content in apples is no more than $0.4 \%$ ) [29], the total acid content of apples in this area satisfies the level, except for the highest terrace apple orchard.

\subsection{Relationships between Soil Nutrients and Fruit Qualities}

The Pearson method was employed to detect the correlation between soil nutrients and fruit qualities (Table 4$)$. The results show that apple soluble solids content has a negative correlation with TK $(p<0.01)$, and a positive correlation with TN $(p<0.01)$ and TP $(p<0.05)$. Vitamin $\mathrm{C}$ has a positive correlation with soil OM $(p<0.01)$. Total acid content has a negative correlation with soil water content in root zone $(p<0.01), \mathrm{OM}(p<0.05)$, and TK $(p<0.01)$, while it has a positive relationship with TN $(p<0.05)$ and TP $(p<0.01)$. According to the research concerning soil water content on fruit quality, the treatment of light water stress (60-70\% of field capacity) on orchards would not only improve the fruit quality by improving the contents of soluble solid and sugar and reduce the total acid, but also keep apple production [34,35]. Apple sugar and acid content determines 
the taste of the apples. The rational use of nitrogen-phosphorus-potassium fertilizer would increase the sugar content and decrease the acid content in apples, otherwise the apple quality would more-or-less deteriorate [36]. Therefore, slight water stress, as well as the rational use of nitrogen-phosphorus-potassium fertilizer and organic fertilizer is an effective approach to maintain apple quality.

Table 4. Correlation analysis between soil nutrients and fruit qualities.

\begin{tabular}{|c|c|c|c|c|c|c|c|c|c|}
\hline & Soil Water & OM & TK & $\mathrm{TN}$ & TP & $\begin{array}{l}\text { Soluble } \\
\text { Solid }\end{array}$ & $\begin{array}{l}\text { Total } \\
\text { Sugar }\end{array}$ & Firmness & Vitamin C \\
\hline $\mathrm{OM}$ & -0.324 & & & & & & & & \\
\hline TK & 0.416 & $-0.634^{* *}$ & & & & & & & \\
\hline $\mathrm{TN}$ & -0.373 & $0.644^{* *}$ & $-0.809 * *$ & & & & & & \\
\hline $\mathrm{TP}$ & -0.450 & $0.806^{* *}$ & $-0.860 * *$ & $0.937 * *$ & & & & & \\
\hline Soluble solid & -0.048 & 0.433 & $-0.610^{* *}$ & $0.599 * *$ & 0.541 * & & & & \\
\hline Total sugar & 0.193 & 0.252 & -0.385 & 0.367 & 0.272 & 0.584 * & & & \\
\hline firmness & 0.210 & 0.044 & 0.383 & -0.468 & -0.402 & -0.027 & 0.054 & & \\
\hline Vitamin C & 0.285 & $0.604^{* *}$ & 0.354 & -0.219 & -0.383 & -0.247 & -0.067 & $-0.551 *$ & \\
\hline Total acid & $-0.768^{* *}$ & $-0.518 *$ & $-0.679 * *$ & $0.543 *$ & $0.615^{* *}$ & 0.458 & 0.139 & -0.083 & -0.420 \\
\hline
\end{tabular}

** significant level of $0.01 ; *$ significant level of 0.05 .

\section{Conclusions}

The impact of relative elevation on apples is concentrated in soil properties (water content and nutrients) and fruit quality. Soil water content decreases when elevation increases, whereas soil nutrient content fluctuates and has significant variation at different elevation of terrace apple orchards $(p<0.05)$. Soil organic matter, total nitrogen, and phosphorus are lower than the standard level of the Loess Plateau, especially organic matter, but total potassium is higher than the standard level.

The impact of relative elevation on apple soluble solids and total acid is not obvious, while the content of apple firmness significantly increases when the elevation raises under similar orchard management conditions. The maximum content of vitamin $\mathrm{C}$ in apples is discovered in the weed-covered orchard. According to the correlation analysis between soil nutrients, including soil water, organic matters, total potassium, total nitrogen, total phosphorus, and fruit quality, the effect of soil nutrients on apple quality is concentrated on soluble solids and total acid. Total acid has a negative relationship with soil water in the root zone, organic matter, and total potassium, while it has a positive relationship with total nitrogen and phosphorus. Soluble solid has a negative relationship with total potassium, but a positive relationship with total nitrogen and phosphorus. Therefore, irrational irrigation or partial use of nutrients, such as more use of nitrogen and less use of phosphorus and potassium, could deteriorate the apple quality.

To maintain good apple quality and develop the apple industry sustainably in this region, we suggest that the amount of irrigation be increased when the elevation rises. Moreover, part of the weed should be kept to cover the orchard, in addition to regular mowing and covering the surface. It not only decreases evapotranspiration and improves water use efficiency-it increases the soil organic matter, leading to good apple quality.

Author Contributions: L.H. performed the conceptualization, data collection, data processing, and manuscript preparation; J.G. provided constructive suggestions to the revised manuscript; M.Z. and S.B. assisted with the sample collection and determination. All authors have read and agreed to the published version of the manuscript.

Funding: This research was funded by the National Key Research and Development Program (No. 2017YFC0504703), the Shaanxi Province Key Research and Development Program (No.2020ZDLSF0603), the National Natural Science Foundation of China (No.41877078, 41371276), the Shaanxi Province Science and Technology Innovation Project (No.2013KTDZ03-03-01).

Institutional Review Board Statement: Not applicable.

Informed Consent Statement: Not applicable. 
Data Availability Statement: The data presented in this study are available on request from the corresponding author.

Acknowledgments: The careful reviews and constructive comments of the editors and anonymous reviewers are gratefully acknowledged.

Conflicts of Interest: The authors declare no conflict of interest.

\section{References}

1. Liang, W.; Bai, D.; Wang, F.; Fu, B.; Yan, J.; Wang, S.; Yang, Y.; Long, D.; Feng, M. Quantifying the impacts of climate change and ecological restoration on streamflow changes based on a Budyko hydrological model in China's Loess Plateau. Water Resour. Res. 2015, 51, 6500-6519. [CrossRef]

2. Fu, B.; Meng, Q.H.; Qiu, Y.; Zhao, W.W.; Zhang, Q.J.; Davidson, D.A. Effects of land use on soil erosion and nitrogen loss in the hilly area of the Loess Plateau, China. Land Degrad. Dev. 2004, 15, 87-96. [CrossRef]

3. Cai, M.; An, C.; Guy, C.; Lu, C. Assessment of soil and water conservation practices in the Loess Hilly Region using a coupled rainfall-runoff-erosion model. Sustainability 2020, 12, 934. [CrossRef]

4. Yang, K.; Lu, C. Evaluation of land-use change effects on runoff and soil erosion of a hilly basin-the Yanhe River in the Chinese Loess Plateau. Land Degrad. Dev. 2018, 29, 1211-1221. [CrossRef]

5. Shi, H.; Shao, M. Soil and water loss from the Loess Plateau in China. J. Arid. Environ. 2000, 45, 9-20. [CrossRef]

6. Zhao, G.; Mu, X.; Wen, Z.; Wang, F.; Gao, P. Soil erosion, conservation, and eco-environment changes in the Loess Plateau of China. Land Degrad. Dev. 2013, 24, 499-510. [CrossRef]

7. Tsunekawa, A.; Liu, G.; Yamanaka, N.; Du, S. Restoration and Development of the Degraded Loess Plateau, China; Springer: Tokyo, Japan, 2014; p. 283.

8. Kang, Y.; Gao, J.; Shao, H.; Zhang, Y. Quantitative analysis of hydrological responses to climate variability and land-use change in the hilly-gully region of the Loess Plateau, China. Water 2019, 12, 82. [CrossRef]

9. Gong, J.; Chen, L.; Fu, B.; Huang, Y.; Huang, Z.; Peng, H. Effect of land use on soil nutrients in the loess hilly area of the Loess Plateau, China. Land Degrad. Dev. 2005, 17, 453-465. [CrossRef]

10. Zhang, X.; Lin, P.; Chen, H.; Yan, R.; Zhang, J.; Yu, Y.; Liu, E.; Yang, Y.; Zhao, W.; Lv, D.; et al. Understanding land use and cover change impacts on run-off and sediment load at flood events on the Loess Plateau, China. Hydrol. Process. 2018, 32, 576-589. [CrossRef]

11. Bai, G.; Pang, L.; Yan, Z.; Wang, J.; Cheng, Q. Formation cause and pruning defense measure of mountain apple with alternate bearing in Northern Shaanxi. J. Anhui Agric. Sci. 2020, 48, 55-64. (In Chinese)

12. Zhong, Y.; Fei, L.; Li, Y.; Zeng, J.; Dai, Z. Response of fruit yield, fruit quality, and water use efficiency to water deficits for apple trees under surge-root irrigation in the Loess Plateau of China. Agric. Water Manag. 2019, 222, 221-230. [CrossRef]

13. Zhang, Y.; Wang, R.; Peng, X.; Zhang, Y.; Ning, F.; Xu, Z.; Wang, Q.; Dong, Z.; Jia, G.; Wei, L.; et al. Changes in soil organic carbon and total nitrogen in apple orchards in different climate regions on the Loess Plateau. Catena 2021, 197, 104989. [CrossRef]

14. Ma, L.; Liu, X.; Liu, G.; Yao, J.; Xing, Z. Problems and new ideas in the development of apple industry in northern Shaanxi. Shaanxi For. Sci. Technol. 2019, 47, 73-77. (In Chinese)

15. Zhang, W.; Sheng, J.; Li, Z.; Weindorf, D.C.; Hu, G.; Xuan, J.; Zhao, H. Integrating rainwater harvesting and drip irrigation for water use efficiency improvements in apple orchards of northwest China. Sci. Hortic. 2021, 275, 109728. [CrossRef]

16. Küçükyumuk, C.; Kaçal, E.; Ertek, A.; Ozturk, G.; Kurttaş, Y.S.K. Pomological and vegetative changes during transition from flood irrigation to drip irrigation: Starkrimson Delicious apple variety. Sci. Hortic. 2012, 136, 17-23. [CrossRef]

17. Bao, S. Soil Agrochemical Analysis; China Agriculture Press: Beijing, China, 2000; pp. 30-103. (In Chinese)

18. Wu, X.; Chen, H.; Li, X. Determination of total acid and total sugar in citrus fruits. Food Res. Dev. 2012, 33, 144-146. (In Chinese)

19. Wu, C. Mensuration and comparation of vitamin C content in fruit. J. Wuhan Univ. Technol. 2007, 29, 90-91. (In Chinese)

20. Mai, C.; Liang, Q. A brief analysis of Brix value determination of the soluble solids Tainnong Mango in Sanya. Hans J. Agric. Sci. 2018, 8, 486-495. (In Chinese)

21. Du, S.; Li, J.; Zhang, R.; Bai, G. Study on suitable parts for apple firmness determination. North. Hortic. 2011, 24, 33-35. (In Chinese)

22. Hao, Z.; Yang, P. Experimental investidation of root system distribution of apple tree. J. Agric. Univ. 1998, 3, 63-66. (In Chinese)

23. Kasim, J. Soil Nutrition Characters of Apple Orchard in Different Ecological Regions on the Loess Plateau; Northwest Agriculture \& Forestry University: Yangling, China, 2014. (In Chinese)

24. Zhang, L.; Li, J.; Fan, P.; Cao, Y.; Kasim, J. Distribution of NPK nutrient content in deep soil profile of typical apple orchards on the Loess Plateau. Acta Ecol. Sinaca 2013, 33, 1907-1915. (In Chinese) [CrossRef]

25. Zhang, D.; Zheng, L.; Han, M.; Gao, C.; Luo, W.; Ma, J. Studies of standard range of the soil nutrients in apple orchard in the Loess Plateau. Acta Hortic. Sinaca 2016, 43, 121-131. (In Chinese)

26. Krishna, M.P.; Mohan, M. Litter decomposition in forest ecosystems: A review. Energy Ecol. Environ. 2017, 2, 236-249. [CrossRef]

27. Błońska, E.; Piaszczyk, W.; Staszel, K.; Lasota, J. Enzymatic activity of soils and soil organic matter stabilization as an effect of components released from the decomposition of litter. Appl. Soil Ecol. 2021, 157, 103723. [CrossRef] 
28. Wang, J.; Pisani, O.; Lin, L.H.; Lun, O.O.; Bowden, R.D.; Lajtha, K.; Simpson, A.J.; Simpson, M.J. Long-term litter manipulation alters soil organic matter turnover in a temperate deciduous forest. Sci. Total. Environ. 2017, 607-608, 865-875. [CrossRef]

29. Jiang, Z.; Wang, K.; Cong, P.; Ma, D.; Gao, R.; Li, W.; Zhang, S. Red Fuji apple. In Agricultural Standards; University of Chinese Academy of Sciences: Beijing, China, 2006; Volume NY/T 1075-2006, pp. 1-9. (In Chinese)

30. Zhou, M. Experimental Research on Rainwater Use Efficiency Enhancement of Typical Terrace Orchard in Loess Hilly Region; Northwest Agriculture \& Forestry University Yangling: Xianyang, China, 2017. (In Chinese)

31. Li, B.; Lin, G.; Liu, F. Relationship between fruit quality, storability and mineral composition of apples. J. Fruit Sci. 1995, 12, 141-145. (In Chinese)

32. Gao, D. Effect of Soil Moisture on Fruit Quality of Red Fuji Apple; Hebei Agricultural University: Hebei, China, 2009. (In Chinese)

33. Li, T.; Zhai, B.; Li, Y.; Liu, L.; Yan, M.; Zhao, Z. Effect of combined application of organic and inorganic fertilizers on quality of Red Fuji apple in dry land. North. Hortic. 2013, 2013, 178-181. (In Chinese)

34. Francaviglia, D.; Farina, V.; Avellone, G.; Bianco, R.L. Fruit yield and quality responses of apple cvars Gala and Fuji to partial root zone drying under Mediterranean conditions. J. Agric. Sci. 2013, 151, 556-569. [CrossRef]

35. Wang, Y.; Liu, L.; Wang, Y.; Tao, H.; Fan, J.; Zhao, Z.; Guo, Y. Effects of soil water stress on fruit yield, quality and their relationship with sugar metabolism in 'Gala' apple. Sci. Hortic. 2019, 258, 108753. [CrossRef]

36. Zhao, Z.; Tong, Y.; Gao, Y.; Fu, Y. Effect of different fertilization on yield and quality of Fuji apple. Plant Nutr. Fertil. Sci. 2009, 15, 1130-1135. (In Chinese) 